\title{
A reprodução do racismo: fazendeiros, negros e imigrantes no oeste paulista, 1880-1914, de Karl Monsma
}

\author{
Review of reproducing racism: farmers, blacks and immigrants in the \\ West of São Paulo, 1880-1914, by Karl Monsma \\ Reproducción del racismo: los agricultores, los negros y los inmigrantes \\ en el oeste de Sao Paulo, 1880-1914, de Karl Monsma
}

Glen Goodman ${ }^{*}$

Com A reprodução do racismo, o professor Karl Monsma (Sociologia na Universidade Federal do Rio Grande do Sul) oferece uma abordagem inovadora das relações cotidianas entre imigrantes, negros e fazendeiros no período da abolição até a primeira década do século XX. No erudito livro, Monsma busca entender os processos humanos que não só produzem, mas reproduzem o racismo, apesar de grandes mudanças institucionais e/ou sociais ao longo do tempo. Ele usa o duplo contexto de abolição e imigração para mostrar um habitus racial em mudança e como os diferentes negociaram essa nova realidade, procurando as melhores condições e resultados possíveis, tanto para o indivíduo quanto para os grupos. Apesar do enfoque geográfico no oeste pau- lista - principalmente no município de São Carlos - a contribuição tanto historiográfica quanto metodológica do livro vai muito além desse contexto.

O livro se divide em duas partes principais. Monsma começa com uma análise teórica e hemisférica do racismo como fenômeno histórico. Primeiramente, ele navega em uma vasta literatura sociológica, antropológica e histórica para teorizar os conceitos "raça," "racialização," e "racismo." Para

\footnotetext{
Doutor em História pela Emory University, EUA. Professor assistente do Departamento de Espanhol e Português na Universidade de Illinois, Urbana-Champaign, EUA.
}

Recebido em 01/04/2016 - Aprovado em 01/09/2016 http://dx.doi.org/10.5335/hdtv.16n.2. 
Monsma, abordagens do conceito bourdieusiano habitus, que tomam em conta as contradições e inconsistências presentes no próprio habitus, parecem as mais produtivas, abrindo novos caminhos para combinar o conceito abstrato com observações históricas do cotidiano. Mudanças sociais ou estruturais desestabilizam o habitus racial numa sociedade-mas por que a persistência da dominação racial? Para Monsma, o racismo se reproduz em tais contextos dada a intersecionalidade do habitus racial com outros contextos humanos: redes socais, instituições, ideologias, etc. Desconsiderando o resto do livro, esse capítulo teórico já seria de leitura importante para qualquer estudante ou pesquisador interessado em tais aspectos da sociedade.

Depois da abordagem teórica, A reprodução do racismo conta a história hemisférica e brasileira da abolição da escravidão como fenômeno social. Olhando para as similitudes e diferenças históricas na América, Monsma oferece vários exemplos de onde e como o racismo perdurou - mudando e se rearticulando - na América. A estrutura familiar, a posição geográfica e o regímen legal em que se encontraram os negros descendentes de escravos, combinados com os desejos e a necessidades dos grandes poderes econômicos (sejam da agricultura ou da indústria), conspiraram em muitos contextos para abrir um espaço no qual o imigrante livre podia melhor aproveitar as condições laborais e também as vantagens oferecidas no habitus racial existente. Com essa abordagem, Monsma descarta as explicações predominantes na historiografia brasileira que confunde o discurso intelectual/eugenista do embranquecimento com as motivações reais dos fazendeiros, ao pagar para trazer mão de obra do exterior. Dito de outra forma, o motivo principal era providenciar suficiente mão de obra para expansão da agricultura sem que a elite corresse o risco de perder o controle econômico e social, uma ameaça corporificada pelos libertos e outros nacionais com seus próprios desejos de mobilidade social. Essa perspectiva também desmente a hipótese de que uma preferência absoluta por empregados brancos desfigurou o mercado de trabalho a favor dos imigrantes. Aqui, Monsma mostra sua facilidade com ferramentas históricas para posicionar o oeste paulistano dentro de um contexto maior, fornecendo ao leitor óculos para ver tanto o global quanto o particular na análise bem detalhada que segue nos próximos capítulos.

A segunda parte do livro analisa de perto as relações cotidianas entre três grupos fundamentais da sociedade paulistana nos finais do século XIX: elites (fazendeiros, policiais, comerciantes, etc.), imigrantes e negros (livres e libertos). Depois do momento de profunda mudança social que representava a abolição, Monsma vê uma desestabilização do habitus racial tanto dos dominantes quanto dos dominados. Os negros lutavam pela igualdade social e legal prometida pela abolição, utilizando uma variedade de estratégias para realizar essa meta e para lidar com as decepções. Os imigrantes também buscavam melhorar suas condições econômicas e sociais, contando com importantes redes sociais e vantagens raciais que cada vez mais se transformaram em armas simbólicas ou literais em conflitos com negros. 
As elites queriam manter sua posição senhorial e continuar contando com mão de obra livre, mas ainda barata e obediente. Esses desafios à ordem racial antiga - ou seja, ao padrão de dominação racial internalizado pelas camadas da sociedade escravocrata deu lugar ao conflito aberto, mas também à internalização de posicionamentos raciais (habitus) e novas relações econômicas entre os grupos.

O que separa $A$ reprodução do racismo de muitos estudos históricos sobre relações raciais é a atenção minuciosa à documentação e ao contexto. Com o olhar sutil de historiador, Monsma usa principalmente a documentação do Judiciário para tecer seu argumento. Por isso, o leitor aprende sobre o papel importante das forças policiais - nesse contexto, pode-se entender as manifestações da influência da elite branca local - na mediação cotidiana desses grupos diferentes. O desejo compartilhado entre negros e imigrantes de serem reconhecidos como membros plenos da sociedade brasileira e melhorar suas posições deu lugar a vários tipos de tensão que acabaram envolvendo a polícia. Fica claro nesses documentos, por exemplo, que as elites locais não necessariamente sempre se solidarizavam com os imigrantes "brancos", fato que fortalece o argumento de que para eles, os imigrantes representavam uma solução ao abastecimento de mão de obra barata, não necessariamente parte de um projeto de embranquecimento. $\mathrm{O}$ trabalho de arquivo leva Monsma a explicar o fenômeno de mobilidade social do imigrante como o resultado de uma mistura de fatores: a lenta inserção dos imigrantes italianos numa posição favorável dentro dos sistemas de dominação racial que se rearticularam ao longo do período estudado, certos fatores estruturais que dificultaram a mobilidade dos negros (em particular na educação) e as vantagens brindadas pelas fortes redes sociais, inclusive com representantes do governo italiano. Assim entendido, essa mobilidade foi tanto produto como produtor dos discursos racializados (e frequentemente racistas) do etos trabalhador do imigrante diante da propalada vagabundagem e fracasso do trabalhador negro.

Embora Monsma empregue seu conhecimento extenso da historiografia tanto brasileira quanto estadunidense para construir um argumento amplo, falta um diálogo com a obra do historiador norte-americano David Roediger. Seu livro clássico, Wages of Whiteness (1991), explora questões muito parecidas, como as noções de diferença e superioridade racial desenvolvidas entre brancos da classe trabalhadora emergente em particular os imigrantes irlandeses - ao longo do século XIX, nos Estados Unidos. Roediger estuda fatores, como a presença de sistemas laborais mistos (escravo/livre), abolição e modernização da indústria, para argumentar que a inserção do imigrante pobre num sistema de dominância racial - seu eventual posicionamento no habitus racial como brancos - representava um salário (wage) extra. Esse posicionamento na hierarquia-em-formação ajudou ao branco pobre a aceitar sua posição subalterna em relação à classe dominante, mesmo que sua situação puramente econômica não fosse melhor. A falta de diálogo com Roediger em $A$ reprodução do racismo é lamentável, pois, poderia fortalecer tanto os argumentos gerais/teóri- 
cos sobre racismo como fenômeno quanto as observações particulares sobre o oeste paulista e o Brasil em geral.

Fica claro que $A$ reprodução do racismo irá se tornar leitura obrigatória para historiadores, antropólogos e sociólogos interessados em vários campos de pesquisa dentro e fora do Brasil: raça/racismo, imigração, abolição, trabalho/labor, violência/crime e estudos rurais, só para especificar alguns. Embora haja um ou outro momento em que o leitor gostaria de mais aprofundamento por exemplo, a caracterização do habitus racial dos imigrantes pré-migração -, o alcance já ambicioso do livro não permitiria acrescentar mais. Pode-se garantir que a obra de Monsma trará provocações e debates. Se tivermos sorte, serão continuações dos vários novos caminhos para pesquisa desbravados por ele nesse livro.

\section{Referências}

MONSMA, Karl. A reprodução do racismo: fazendeiros, negros, e imigrantes no oeste paulista, 1880-1914. São Carlos: EdUFSCar, 2016.

ROEDIGER, David. The Wages of Whiteness: Race and the Making of the American Working Class. London: Verso, 1991. 